\title{
Characteristics of Students in the First Grade of Primary School and Initial Teaching of Reading and Writing
}

\author{
Aynur BíLíR*
}

\begin{abstract}
Children in the age group of 6-7 starting the first grade of primary school show big differences from the standpoint of their abilities, development, interests, requirements and school maturity. From the standpoint of their general characteristics, they are in the play age, have a short span of interest, concrete thinking and global perception characteristics. The best method suiting these characteristics in the initial teaching of reading and writing is the sentence method. The "sound-based sentence method" adopted by the Ministry of National Education in the initial teaching of reading and writing in the New Primary Education Curriculum is not suitable for the learning characteristics of children. This method may be much more suitable for adults with developed skills of seeing details and establishing logical links between them.
\end{abstract}

Key Words: initial teaching, primary education, students' characteristics, teaching methods, teaching reading and writing

\section{SUMMARY}

Characteristics of Students in the First Grade of Primary School and Initial Teaching of Reading And Writing

There are significant characteristics of first grade students in primary schools comparing to other grades of elementary school students. Children who enrolled in first grade and are in 6 to 7 years age group have differences by talents, growth speed, interests, needs and school maturity characteristics.

\footnotetext{
*Dr., Muğla University, Faculty of Education
} 
Responsibility of the teacher is to educate the every single student accordance to their maturity. First grade students in primary schools are in play period, and they have short time attention period, concrete thinking ability, and kind of general perception as general characteristics. Another words, child perceive the total not as separately. Because of the reason, it is the best method which fits child development and psychology is sentence (analysis) method. When this method was used to teach in reading and writing, children can have ability to read correct, meaningfull and fast.

Reading and writing practices by the sentence analysis method should start with short order sentences which students can understand easily, then those sentences should be divided into words and words into syllables. Afterwards, students perceive the sounds of the letters in the syllables. New syllables, words and sentences should be constructed with the words, syllables and letters gained by this analysis.

"Sound based sentence method" which Ministry of National Education accepted in New Primary Education Curriculum is not suitable for learning characteristics of children at 6 to 7 years old age who have just started to first grade of primary schools. Students do not realize to understand the sound, since their attention focus onto recognition of sound. This method can be more suitable for characteristics of adults who already developed their skills in abstract thinking, who are aware details and making a connection between them. 


\title{
İlköğretim Birinci Sınıf Öğrencilerinin Özellikleri ve İlk okuma Yazma Öğretimi
}

\begin{abstract}
Aynur BíLíR*
ÖZ. İlköğretim birinci sınıfa başlayan 6-7 yaş grubu çocuklar; yetenekleri, gelişme hızları, ilgileri, gereksinimleri ve okul olgunlukları bakımından büyük farklar gösterirler. Genel özellikleri bakımından bu çocuklar oyun çağında olup, ilgileri kısa, somut düşünme ve toptan algılama özelliğine sahiptirler. İlkokuma yazma öğretiminde bu özelliklere uygun düşen en iyi yöntem, cümle yöntemi'dir. Yeni İlköğretim Programı çalışmalarında Milli Eğitim Bakanlığının, ilkokuma yazma öğretiminde benimsediği "ses temelli cümle yöntemi" çocukların öğrenme özelliklerine uygun değildir. Bu yöntem daha çok, ayrıntıları görme ve aralarında mantıksal bağ kurma becerileri gelişmiş yetişkinler için uygun olabilir.
\end{abstract}

Anahtar Sözcükler: ilköğretim, öğrenci özellikleri, öğretim yöntemleri, okuma yazma öğretimi

\section{GíRISS}

İlköğretimde birinci sınıfın, diğer sınıflara göre önemli bir özelliği vardır. Kentsel yaşam alanlarında okul öncesi eğitim kurumlarından yararlananların okul yaşamlarına uyumları kuşkusuz daha kolay olmaktadır. Ancak okul öncesi eğitim olanaklarından yararlanamayan çocuklar, ilk kez bu sınıfta okul hayatına başlamakta, alışmakta ve öğrenciliğin gereklerini burada öğrenmektedir. Öğrenci merkezli eğitimi temel alan ilköğretimin görevi, çocuğu yormadan, yıldırmadan, örselemeden, onun neşesini kaçırmadan, sevecen bir tavırla onun yeni duruma uyum sağlamasını kolaylaştırmaktır.

Ailenin aşırı korumacılığında yetişmiş, okul öncesi eğitim hizmetlerinden yararlanmadan okula yeni gelen çocukların çoğu, okuma ve yazmaya başlamaları için gerekli fiziksel, duygusal, toplumsal olgunluğa erişmemiş ve bazı ön becerilerden yoksun olabilir. Baymur'un da belirttiği gibi;

*Dr., Muğla Üniversitesi Eğitim Fakültesi 
"Bu yaştaki çocukta nabız daha süratle atar, nefes alıp verme daha siktır. Süratli boy atma dolaylsıyla, kas kuvveti zayıftır. Bu yüzden çocuk uzun müddet aynı vaziyette kalamaz. Küçük eklemler gerektiği şekilde dakik, kati hareketler yapmak, tarzda gelişmemiştir. Bu durum bizim (birinci sinıf ögretmeni) için büyük bir önem taşır. Çünkü okul, çocuktan yazı ve resim gibi, küçük ve kati hareketler istemektedir. Duygusal ve devrimsel sinirler, yetişkinlerde olduğundan daha ziyade birbirine bağlıdır. Dışarıdan gelen bir uyarım, hemen otomatik denecek şekilde, bir tepkiye sebebiyet verir. Bu hal çocuğun harekete karşı olan fevkalade ihtiyacını izah eder. "(Baymur, 1947, s.7)

Okul çağına giren çocuğun büyük bir hareket ve oyun ihtiyacı vardır. $\mathrm{Bu}$ bakımdan başlangıçta okul-içi faaliyetlere olabildiğince oyun havası verilmeli, yavaş yavaş, okul etkinliklerine geçmelidir. Ayrıca birinci sınıf öğretmeni, birinci sınıfa gelen çocukların okulla ilgili her şeyi yeni öğreneceklerini sürekli göz önünde tutmalı ve defter-kitap açmak, kalem kullanmak gibi basit şeyleri bile yapmak için kendilerine yol gösterilmesi gerekli olduğunu unutmamalıdır.

\section{Okul Olgunluğu ve Hazırlık Çalışmaları:}

Okul öncesi eğitim olanaklarından yararlanmadan okula gelen çocuklar için bir hazırlık çalışması yapmak gereklidir. $\mathrm{Bu}$ hazırlık çalışmasının niteliğini ve süresini öğrencilerin hazır oluşluk (okul olgunluk) düzeyi belirlemektedir. İlkokuma yazmaya hazırlık çalışmalarının süresi okul olgunluk düzeyine göre bir haftadan, altı haftaya kadar değişebilmektedir.

Bir şeyi öğrenmeye hazır olmayan çocuğa, onu öğretmeye kalkmak sadece verimsiz olmakla kalmaz aynı zamanda çocukta başarısızlığa, hayal kırıklığına ve aşağılık duygusunun oluşmasına yol açar. Böyle bir olumsuzluk yaşayan çocuk yeteri kadar olgunlaştı̆̆ zaman bile kendi yaşındaki çocukların başardığı işleri yapmaya cesaret edemez. Çocukta gelişen aşağılık duygusu, onun yaratıcıllı̆ını ve fikri ilgilerini baltalar. İyi bir öğretmen, çocuğa bir şey öğretmeye geçmeden önce, onun bunu öğrenmeye hazır olup olmadığını yoklamalıdır. İlkokuma yazma öğretimine başlamadan önce çocukta bazı niteliklerin geliştirilmesine çalışmalıdır.

$\mathrm{Bu}$ devrede öğretmen, öğrencileri tanıma firsatı bulur. Öğrencilerin elgöz koordinasyonu, kalem tutma, yazı yazma, dinlenme ve konuşma becerileri bu devrede geliştirilmeye çalış1ır (Cemlaoğlu, 2000.s.85).

Birinci sınıfa gelen çocuklar eğer okul öncesi eğitim kurumuna gitmemiş ise, kalemi defteri ilk kez bu sınıfta tanıyorlar ise, bunlarla yapılacak hazırlık çalışmaları bir-bir buçuk ay sürebilir. Çünkü bu çocuklar, ellerine kalem verildiğinde kalemi çok sıkı bir şekilde, sanki bütün vücutlarıyla tutarlar ve kalemi hareket ettirmek istediklerinde bütün vücutları 
katılaşır ve topyekun hareket ederler. Böyle bir durumda, önce kolun vücuttan, daha sonra bileğin (elin) koldan ayrı hareket etmesi sağlanır. Diğer bir deyişle, yazı çalışmalarına başlamadan önce, öğrencilerin kas gelişimi güzel bir yazı yazmaya hazır oluncaya dek, kol, el ve parmak kaslarını geliştirici çalışmalar yapılmalıdır. Bu da zaman alır. Bunun için önce kol havaya kaldırılarak havada soldan sağa, yukarıdan aşağıya serbest hareketler yaptırılır. Kum masasında ve siraların üzerinde parmakla hareketler yaptırılır. Böylece kolun vücuttan bağımsız hareket etmesi sağlanır Daha sonra, kil veya hazır macun hamurları ile küçük el ve parmak kaslarının gelişimi için çalışmalar yapılır. El, koldan; parmaklar da elden ayrı hareket etmeye başlayınca normal çizgi çalışmalarına başlanabilir. Bu çalışmalar sınıfça yapılabileceği gibi, hazır oluş düzeylerine göre bireysel ya da oluşturulacak seviye grupları ile grupça da yapılabilir. Öğretmenin acele etmeden kaygıya kapılmadan planlı bir şekilde bu çalışmaları sürdürmesi gerekir. Çünkü araştırmalar göstermiştir ki; bazı nitelikleri yüzünden ortalama bir öğrenciden daha yavaş öğrenen bazı öğrencilerin olabileceği bu öğrencilerin de etkili bir şekilde öğrenebileceklerine; ancak bu sonuca erişebilmek için bu gibi öğrencilerin daha çok zamana, dikkate ve kaynağa gerek duyacakları belirtilmektedir (Bloom, 1995, s.256).

İlkokuma yazmanın amacı öğrencilere her ne şekilde olursa olsun okuma becerisi kazandırmak değil, çocuğun öğrenme özelliklerini dikkate alan çağdaş yöntem ve tekniklere göre iyi bir Türkçe becerisi kazandırmaktır. İlköğretim okullarında Türkçe öğretiminin amacı; Milli Eğitimin genel amaçlarına ve temel ilkelerine uygun olarak:

"1-Öğrencilere, görüp izlediklerini dinlediklerini, okuduklarını tam ve doğru olarak anlama gücü kazandırmak.

2-Öğrencilere, görüp izlediklerini, dinlediklerini, okuduklarını, incelediklerini ve düşündüklerini, tasarladıklarını söz yada yazı ile doğru ve amaca uygun olarak anlatma beceri ve alışkanlığını kazandırmak;

3-Öğrencilere Türkçe'yi sevdirmek, Türkçe'nin kurallarını sezdirip kavratmak; Türkçe'yi gelişim süreci içinde bilinçle, özenle ve güvenle kullanmaya yöneltmek.

4- Öğrencilere, dinleme, okuma, alışkanlık ve zevkini kazandırmak; estetik duygularının gelişmesinde yardımcı olmak.

5-Çeşitli etkinliklerle öğrencilerin kelime dağarcı̆̆ını zenginleştirmek.

6-Çocukların, ulusal duygusunu ve coşkusunu güçlendirmede kendi payına düşeni yapmak. 
7- Sözlü ve yazllı Türk ve Dünya kültür ürünleri yoluyla, Türk kültürünü tanıma ve kazanmalarında; Türk yurdunu ve ulusunu, doğayl, hayatı, insanliğl sevmelerinde yardımcı olmak.

8-Öğrencilere, bilimsel, eleştirici, doğru, yapıcı ve yaratıcı düşünme yollarını kazandırmada Türkçe dersinin payına düşeni gerçekleştirmektir”.

\section{İlkokuma-Yazmada Yöntem Sorunu}

Yazının bulunmasından günümüze kadar okuma-yazma öğretiminde harf yöntemi baskın olmak üzere, pek çok yöntem kullanıla gelmiştir. Her yöntemin kendine özgü faydalı ve sınırlı yönleri bulunmaktadır.

İlkokuma-yazmada kullanılacak yöntemin türünü bir ölçüde öğretim sürecinde yer alacak bireylerin gerçek durumları belirlemektedir. Örneğin okula yeni başlayan çocuklar somut düşünme çağında bulunduklarından, tek başlarına bir şey ifade etmeyen harfler ve onlara ait sesler soyut olduklarından bunlar çocuklar tarafından öğrenilmesi hem zor,-ancak ezberlenebilirler- hem de sıkıcıdır. Bu bakımdan harf ya da ses temelli cümle yöntemi öğrenci merkezli eğitim yaklaşımıyla çelişmektedir. Çünkü öğrenci merkezli eğitim yaklaşımında, öğrencinin öğrenme özellikleri, ilgileri, yetenekleri göz önünde bulundurulur.

Harf, ses, hece ve sözcük/kelime yöntemleri özünde ulama ve ekleme mantı̆̆ıyla işlediklerinden, önce ses ve sembollerin tanınması, (ezberlenmesi) sonra bunların birbirine ulanması (çatılması) ve eklenmesi gerekmektedir. $\mathrm{Bu}$ süreç hem okumada, hem de yazmada hızı düşürmektedir. Hatta öyle ki bu ulama ve ekleme zihinsel bir süreç olduğundan çocukta alışkanlık yapmakta ve sessiz okuma sırasında da devam etmektedir. Bu da bireyin sessiz okumada da hızlı okuyamamasina neden olmaktadır. Bu yöntemle okuma-yazma öğrenen öğrencilerin ileride "hızlı okuma teknikleri" konusunda eğitilmeleri zorunlu hale gelmektedir. Ses temelli cümle yöntemini savunanların bu gerçeği görüyor olmaları gerekir.

Fonetik olmayan, kelimelerin yazılışı ve okunuşu farklı ve bir sesi birden çok harfle ifade eden dillerde harf yöntemini benimsemek bir zorunluluk olabilir. Örneğin Almancada "okul" ve "Alman" sözcüklerinin yazılışı ve okunuşu farklıdır.

"Okul" sözcügünün yazılışı "Schule", okunuşu ise "şule" dir. "ş" sesini vermek için "sch" gibi üç harf kullanılmaktadır. Aynı şekilde; "Alman" sözcüğünün yazılış1 "Deutsch" , okunuşu ise " Deuç" dur. Bu sözcükte de "ç" sesini vermek için "tsch" olmak üzere dört harf kullanılmaktadır. Oysa "okul” ve "Alman" sözcükleri Türkçede yazıldığ 1 gibi okunmakta, okunduğu (söylendiği) gibi de yazılmaktadır. 
Bütün bu açıklamalar ve Türkçenin dil yapısı, çocuğun toptan algılama özelliği ve gözün satır üzerinde sıçramalarla ilerlemesi gibi özellikler Türkiye'de ilkokuma yazma çalışmaları için cümle yönteminin daha uygun olduğunu göstermektedir.

Cümle yöntemiyle okuma-yazma daha uzun sürede gerçekleşir. Ancak cümle yöntemiyle ilkokuma yazmayı öğrenen çocuğun okuması da, yazması da hızlı olmakta ve okuduğunu anlama becerisi gelişmektedir. Cümle yöntemiyle yapılan okuma yazma çalışmalarına ilişkin ileri sürülen başarısızlıklar, yöntemle ilgili olmayıp, yöntemin gerektirdiği yeterliklerin öğretmene kazandırılmamış olmasıyla ve özellikle birleştirilmiş sınıflı ilköğretim okullarındaki öğretmenlerin gereksinim duydukları mesleki rehberlik hizmetlerini alamamaları ve mesleksel yalnızlık içine düşmeleriyle yakından ilgilidir(Çınar,2002:56;2004:38). Milli Eğitim Bakanlığı, öğretmenlik mesleğinin gerektirdiği yeterlikler olmadan on binlerce üniversite mezununu sınıf öğretmenliğine atamıştır. Bugün bu öğretmenler özellikle cümle yöntemiyle ilk okuma yazma öğretiminde mesleki yetersizlik nedeniyle başarı gösterememektedirler. Yeterlik kazandırmak zor ve zaman alıcı bir iş olduğundan, Bakanlık, bu öğretmenlere cümle yöntemiyle okuma yazma öğretiminin gerektirdiği yeterlikleri kazandırma yerine; kısa süreli kurs ve seminerlerle eğitimli her yetişkinin kazanabileceği ses temelli cümle yönetimini kazandırarak sorunu (yanlışı, yanlışla) çözme yoluna gitmektedir.

Ses temelli cümle yöntemi aslında harf yönteminden çok farklı bir şey değildir. Çünkü çocuk harfin sesini tanıyıp onu seslendirmesi için önce şekil olarak harfi öğrenecektir. Bir başka anlatımla çocuk harfi görecek onu kavram, şekil biçim olarak algılayacak daha sonra seslendirecektir. Harfin doğal sesini vererek yapılacak ses temelli okuma yazma çalışmalarında, harf yöntemiyle yapılan ulamalı-(eklemeli) seslendirmedeki hataları önlenmiş olmaz. Sesin fiziki şekli olan harfin zihinde canlandırılması, daha sonra seslendirilmesi işlemi değişmediğinden, parçadan bütüne giden harf, ses, hece, sözcük (kelime) den hareketle cümleye ulaşan yöntemler okumayı öğrenmenin süresini kısaltabilir. Ancak tecrübe ile sabittir ki bu yöntemler, okumanın hızını da, anlamını da düşürmektedir. Ses temelli cümle yöntemiyle birey beş altı hafta gibi çok kısa bir sürede okumaya geçebilir. Ancak bu anlamlı bir okuma olmayıp, yalın bir seslendirmedir.

Fonetik (ses) yöntemde bir kelimeyi okumak için harflerin sesini tanımak gerekmektedir. Harfin adı ile sesinin farklı olduğu dillerde uygulanabilme şansı olan bir yöntemdir(Güneş,1997:138). Fonetik yöntemde öğrencinin dikkati doğal olarak sesi tanımaya çevrildiğinden öğrenci anlamayı gerçekleştirememektedir (Gray,1975:90).

Ses temelli cümle yöntemi olsa olsa mantıksal gelişimini tamamlamış yetişkinler için uygun olabilir. Özellikle okuma her zaman eleştirel 
algılamayı, yorumu ve okunan şeyin yeniden yazılmasını gerektirir. Bunu da okuma yazma aşamasında ancak yetişkinler yapabilir. Yetişkinlerin yaşantılarından alınan anlamlı sözcük ve kısa cümlelerle yapılan okumayazma çalışmalarının, yetişkinlerin öğrenmelerinde etkili olduğu görülmüştür (Freire ve Macedo, 1998: 80). Yetişkinlerin öğrenmesinde onların, çözümleme ve birleşim yapma yeteneklerinin gelişmiş olmasının rolü çok büyüktür. Yetişkinler bu özelliklerinden dolayı cümle içinde sözcüğü sözcük içinde heceyi, hece içinde de harfi (sesi) daha kolay ve çabuk tanımlar (Binbaşığlu, 2004, s.60; Cemaloğlu, 2000, s.74); çünkü onlar, ayrıntıları görme ve aralarında mantıksal bağ kurmada deneyim sahibidirler. Ayrıca okumayı öğrenmek için uzun zamanları da yoktur. Çocuklar açısından okuma yazma öğretiminin amacı, çocuğa her ne şekilde olursa olsun okuma becerisi kazandırmak değil, çağdaş yöntem ve tekniklere uygun okuma yazma becerisi kazandırmaktır (Köksal,2001,s.38).

Bugün sahip olduğumuz verilere göre çocuk gelişimine, psikolojisine uygun düşen en iyi yöntem cümle (çözümleme) yöntemidir. Bu konuda yapılan araştırmalar gözün okuma sırasında satır üzerinde düz bir yol izlemediğini, okumanın göz sıçraması sonucu meydana geldiğini ortaya koymuştur. Öte yandan da "Gestalt Psikolojisi"ne göre çocuklar, çevresindeki nesne, olay ve şekillere "bütün" halinde tepkide bulunurlar. Ayrıntılarla ilgilenmezler. Yani "çocuk "toptan" (global) bir algılamanın özelliğine sahiptir. Bir şeyi bütün olarak kavrar. Okuma yazma bu yöntemle ögretildiği zaman, çocuk doğru, hizlı ve anlamlı okuma becerisini daha kolay kazanır" (Kavcar ve diğerleri, 2004:30). Daha açık bir ifade ile; Geştalt kuramcılarına göre birey, bütünü parçalarına ayrıştırarak değil, anlamlı örgütlenmiş halinde algılar. Daha sonra bütün ile parçaları arasındaki ilişkileri keşfeder. Ayrıca algılamada basitlik, benzerlik, yakınlık, devamlılık, şekil ve zemin iliş̧ileri önemlidir. (Binbaşığlu, 2004, s.61; Cemaloğlu, 2000, s.68; Köksal, 2001, s.42). Bu sebeple okuma yazmaya harflerden başlamak çocuk psikolojisine aykırı düşer (Göğüş, 1968:9).

Gestaltcılara göre "bütün" onu oluşturan parçaların toplamından ayrı, başka ve fazla bir şeydir. Bu bakımdan öğrenme yaşantıları, anlamlı bir bütün halinde yapılandırılmalı ve uygulanmalıdır. "Çünkü gerçek dil birimini oluşturan ne kelime, ne hece, ne de harftir. Sadece cümledir...Buradan hareketle, okuma yazma ögretimi anlaml cümlelerle gerçekleştirilmelidir” (Güneş,2000:46).

Yirminci yüzyılın ilk çeyreğinde yapılan deney ve araştırmalar ilkokuma-yazma öğretiminde en etkili yöntemin cümle yöntemi olduğunu ortaya koymuştur. Bunu ortaya koyanlar Gestalt Psikolojisinin temsilcileridir. Bunlara göre; yukarıda da değinildiği gibi; insanlar, özellikle çocuklar çevresindeki nesne, olay ve şekillere bir bütün halinde tepkide bulunmaktadırlar. Yani birey "toptan” (global) bir algılama özelliğine 
sahiptir. Bunlara göre "bütün" onu oluşturan parçaların toplamından başka, ayrı, fazla bir şeydir.

Bir melodi onu oluşturan notalardaki seslerden nasıl ayrı, başka ve fazla bir şeyse, bir cümle de onu oluşturan sözcük, hece, harf ve seslerden ayrı, başka ve fazla bir şeydir. Birey, önce bir nesnenin ayrıntılarına değil, onun bütününe tepkide bulunur. Parçalara tepkide bulunmak, bunları incelemeye yönelmek özel bir eğitim çaba ve dikkat işidir. Bu ancak gerektiğinde yapılır. Onun için normal olan böyle bütünsel tepkidir (Binbaşığlu, 2004:61).

Okuma-yazma öğretimi için çocukların sahip olmaları gereken olgunluk ve temel beceri düzeylerinin nasıl olması konusunda yeterli bilgi sahibi olmayan, ayrıca öğretilecek cümlelerin çocuğun kendi yaşantısı ve yakın çevresinden alınmasını, kısa, anlamlı ve son öğretilen cümle ile önceden öğretilenlerin ilgili ve bağlantılı olmasının, bunun çözümleme aşamasında önemli olduğunu, cümle çözümlemesine nasıl ve ne zaman geçeceğini, sözcük, hece ve seslerin nasil sezinleteceğini bilmeyen, buna göre yetişmeyen, yetiştirilmeyen öğretmenlerin cümle yöntemiyle okuma-yazma öğretmeleri beklenemez. Öğretmen adaylarının öncelikle cümle yönteminin gerektirdiği yeterlikleri kazanmaları sağlanmalıdır.

\section{İkokuma-yazmaya hazırlık}

Okula yeni gelen çocukların çoğu, okuma ve yazmaya başlamaları için gerekli fiziksel, duygusal, toplumsal olgunluğa henüz erişmemiş ve bazı ön becerilerden yoksun olabilir. $\mathrm{Bu}$ durumdaki çocuklar için bir hazırlık çalışması yapmak gereklidir. $\mathrm{Bu}$ çalışma öğrencilerin özellikleri ve sorunlarına göre önceden belirlenip, bir plan çerçevesinde yapılmalıdır. Bu hazırlıklar; okuma-yazma için gerekli araç ve gereçleri kullanabilme becerilerini kazandırma çalışmalarının yanı sıra;

a)Yazmaya hazırlık,

b)Okumaya hazırlık olmak üzere iki başlık altında ele alınabilir.

\section{Yazmaya hazırlık}

Kalem ve defter tutmanın öğretilmesinden sonra, öğrencilere önce sayfa üzerinde serbest çizgiler çizdirilmeli, daha sonra tekniğine uygun olarak hazırlanmış alıştırmalar üzerindeki çalışmalarla yazının;

Soldan $\longrightarrow$ sağa yazılacağı fikri verilmeli, yukarıdan aşağıya, soldan sağa, yuvarlak, eğik çizgiler çizme alışkanlığı vermek için çeşitli alıştırmalar yaptırılmalıdır. Aşağıda örneği verilen altı temel çizgi çalışması üzerinde yeterince durulmalıdır (Öz,1998) 


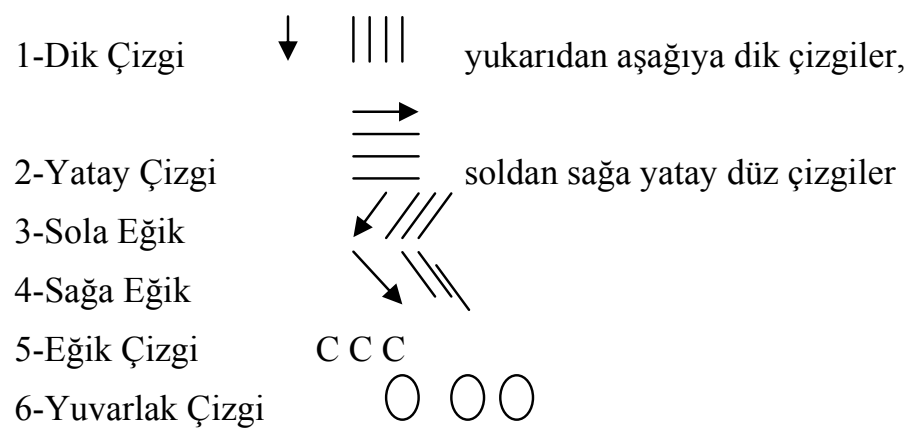

İlk haftalardaki hazırlık alıştırmalarında çizgi ve biçimlerin ağır ağır, doğru ve güzel yapılması sağlanmalıdır. Çocukların havada, sıra üzerinde, kum masasında, yazı tahtasında, kağıt ve benzeri şeyler üzerinde yapacakları yazı çalışmaları devamlı bir şekilde kontrol edilmeli ve özensiz yazı yazan çocuklar üzerinde durularak, onların kötü bir alışkanlık kazanmaları önlenmelidir.

Birinci sınıfta ilkokuma ve yazmaya başlarken, programın çizdiği yazı esaslarına uygun olarak büyük ve küçük harfler birlikte öğretilmelidir. Çünkü günlük hayatta çocuğun karşılaştığı kitap, dergi ve gazete gibi basılı yayınlarda büyük ve küçük harfler birlikte kullanılmaktadır (Aydoğdu ve Aköz,1960:44). Çocuklara verilecek ilk cümle ve kelimelerin kısa, az heceli ve harfli olmasina, kolay yazilabilen harflerden kurulu bulunmasına dikkat edilmelidir. Kelime ve cümleler kavratılırken harflerin yazılış biçimine ve yönüne, satırda kapladıkları yere, büyük harflerin, küçük harflerle olan ilişkisine, oranlarına, büyük harflerin küçültülmüş biçiminden başka bir şey olmayan (cç, iij, oö, p, sş, uü, v, z) harfleriyle (Aydoğdu ve Aköz,1960.s, 55), küçük değişikliklerle büyük harflerin birer benzeri olan (b, e, f, g, ğ h, $\mathrm{k}, \mathrm{l}, \mathrm{m}, \mathrm{n}, \mathrm{t}, \mathrm{y})$ harfleri üzerine öğrencilerin dikkati çekilerek, harflerin doğru ve örneklere uygun yazılması sağlanmalıdır (MEB,1968:114).

Birinci sınıfta yazı, öteki sınıflarda olduğundan çok daha fazla okuma ile kaynaşmış bir derstir. Bu nedenle okuma yazma etkinlikleri birlikte yürütülmeli ve biri diğerine yeğlenmemelidir.

El yazısı ilköğretim okullarının kazandırması gereken en önemli becerilerden biridir. El yazısının öğrenilmesi, ilk okuma yazma sırasında başlar. (Göğüş, 1982:.22 ). Bu konuda yapılacak çalışmalar, uygulanacak yöntem ve biçimler İköğretim Türkçe programlarında yer almaktadır(MEB,1997: TD.:.2482).

İlköğretim birinci sınıf öğrencilerinin ilkokuma yazma çalışmalarının başlangıcında, dik ve köşeli harflere göre, dik ve keskin köşeli olmayan 
yuvarlak harfleri daha kolay ve daha düzgün, güzel yazdıkları görülmektedir. Öğrencilerin bu özellikleri dikkate alındığında, Milli Eğitim Bakanlığının yeni program çalışmalarında dik yazı yerine bitişik ve eğik yazıyı ilköğretimin ilk sınıflarından itibaren benimsemiş olması, çocukların işlek ve güzel bir el yazısı becerisi kazanmaları açısından olumlu bir gelişmedir(MEB,2004:111-128).

\section{Okumaya Hazırık}

Okumanın soldan $\longrightarrow$ sağa doğru gözün kavrama alanını genişletmek, bir satır bitince alt satıra geçme alışkanlığ çalışmalar yaptırılmalıdır. Böylece yazılanların bir anlatım yolu olduğu anlayışı sezdirilmeye çalışılmalıdır.

Öğrencilerin dilimizdeki sözcükleri anlamlarıyla, doğru yazılış ve söylenişleriyle öğrenmelerini sağlamak, onların sözcük dağarcıklarını zenginleştirmek Türkçe öğretiminin amaçlarından biridir. Çocuklarda sözcük dağarcığının önemli ölçüde ve hızla zenginleştiği dönem ilköğretim dönemidir(Kavcar ve diğerleri,2004:6). İlkokuma ve yazma çalışmalarına geçebilmek için çocukların sözcük dağarcıkları gerekli ölçüde geliştirilmelidir. Birinci sınıfın ilkokuma yazma çalışmaları bu sınıfın bütün öğretim etkinliklerinin ayrılmaz bir parçasıdır. Sınıf ve okul hayatı, aile hayatı gibi yakın çevre; birlikte yaşanan sosyal ve doğa olayları, okumayazma için çok doğal firsatlar yaratır. Öğretmen bu firsatlardan yararlandığ1 ölçüde başarılı olabilir.

İlkokuma ve yazmaya öğrencilerin anlayabileceği kısa emir cümleleri ile başlamalı, zamanla bu cümleler kelimelere, kelimeler hecelere bölünmelidir. Daha sonra heceler içindeki harflerin sesleri sezdirilmeye çalışılmalıdır. Bu çözümlemeler sonunda elde edilen kelime, hece ve sezilen harflerle yeni cümle ve kelimeler kurularak kısa anlamlı okuma metinleri oluşturulmalıdır.

Cümlelerin, kelimelerin ve hecelerin bölünmesini kolaylaştırmak için öğretmen, aynı kelimeleri içine alan cümlelerden ve içinde aynı heceler bulunan kelimelerden yararlanmalıdır. Üzerinde durulan cümle ve kelimeleri öyküler, masallar, tekerlemeler içinde kullanmaya önem verilmeli ve ilkokuma ve yazma konularının öğrencilerin ilgisini çekecek nitelikte olması sağlanmalıdır. İlkokuma-yazma çalışmalarında bütün seslerin (harflerin) gereği kadar tekrarlanmasına özen gösterilmelidir. Öğrencilere okumasını ögrendikleri cümle ve kelimeler aynı zamanda yazdırılmalıdır.

Öğrencinin günlük yaşantısından güç alan bir ilkokuma ve yazma öğretimi, öğretmenin genel bir ilkokuma kitabına bağlı kalmakla birlikte, sınıf ve çevre özelliğine göre cümleler ve metinler üzerinde çalışmasını da gerektirir. İlkokuma yazma çalışmalarında ayrıca bol ve pedagojik 
değerlerden oluşan bir takım araç ve gereçlere de yer verilmelidir(Köksal, 2001; MEB,1968). Bu araç gereçlerin bazıları şunlardır.

a) Kas geliştirici kil ya da renkli hamur macunu, b) Kum masası, c)Yazı tahtası, d)Büyük, küçük fişler, e) Çözümleme levhası, f)Okuma parçaları, g)Harfler (kağıt, plastik) vb.

Okumayı ve yazmayı öğretme işinde, alıştırmanın büyük bir rolü vardır. Ancak bir şeyin gereksiz tekrarlanmasının yararı yoktur. Gereksiz tekrar dikkati ortadan kaldırabilir.

Cümleler ilgi çekici olmalı, fikralar ve sözler yeri geldikçe oyun biçiminde tekrarlanmalıdır. Öğretmen, ayrıca; belli bir cümleyi tahtaya ve defterlere ayrı ayrı yazdırarak okutmalı ya da cümlenin başka fişlere yazılmış biçimlerine dikkati çekmelidir.

\section{SONUC}

İlköğretim birinci sınıf öğrencileri, yetenekleri, gelişme hızları, ilgileri, gereksinimleri ve okul olgunluk düzeyleri bakımından birbirlerinden büyük farklılıklar gösterirler. Birinci sınıf öğretmeni, bu durumu bilerek işe onları her yönüyle tanımaya çalışmakla başlamalıdır.

İlköğretimde öğretmenin görevi, her çocuğu kendi gücüne göre yetiştirmektir. Bunu yaparken hareket noktası, çocuğu başarısızlık korkusu altında yetiştirmeye çalışmak değil, onu başarılı olmaya, çalıştıkça başarısını artırmaya ve başarısı yönünde ilerlemeye özendirmek olmalıdır.

İlköğretim birinci sınıfa yeni başlayan 6-7 yaş grubu çocuklar genel özellikleri bakımından oyun çağında olup, ilgileri kısa, somut düşünme döneminde ve toptan algılama özelliğine sahiptirler. Çocukların bu özelliklerine uygun düşen en iyi yöntem cümle (çözümleme) yöntemidir. Bu yöntem, okuma yazmaya tam anlamlı sözlerden başlanarak kelimelere, hecelere ve harflere gitmek yoludur. İlkokuma yazma bu yöntemle öğretildiği zaman, çocuk doğru,hızlı ve anlamlı okuma becerisini daha kolay kazanmaktadır.

Yeni İlköğretim Programı çalışmalarında Milli Eğitim Bakanlığının, ilkokuma yazma öğretiminde benimsediği "Ses temelli cümle yöntemi", ilköğretim birinci sınıfa yeni başlayan 6-7 yaş grubu çocukların öğrenme özelliklerine uygun değildir. Bu yöntem soyut düşünme, ayrıntıları görme ve aralarında mantıksal bağ kurma becerileri gelişmiş yetişkinlerin öğrenme özelliklerine daha uygun düşebilir.

\section{Öneriler}

Birinci sınıf öğretmeni, sınıfındaki öğrencilerin her birini bütün özellikleriyle tanımaya çalışarak, onların özel gereksinimlerini 
belirlemelidir. Öğretmen, öğrencilerin gereksinimlerini nasıl karşılayacağını, neyi, nasıl öğreteceğini planlamalıdır. Okul olgunluğunun oluşmasında önemli rolü olduğu bilinen okulöncesi eğitim kurumları, bir kamu hizmeti olarak kırsal alanları içine alacak şekilde yaygınlaştırılmalıdır.

Birinci sınıf öğretmeni; her şeyden önce sabırlı, sevecen, anlayışlı, hoşgörülü ve güler yüzlü olmalıdır. Öğrencilerinin iyi yönlerini, başarılarını görebilmeli ve takdir etmekten çekinmemelidir. Her öğrencinin başarısını kendi gelişimi içinde değerlendirmeli, diğer öğrencilerle kıyaslamamalıdır.

İlkokuma yazma öğretimi yöntemleri hakkında bilgi ve beceri sahibi olmalı, öğrencilerin öğrenme özelliklerine göre uygun düşen yöntemi seçip başarı ile uygulayabilmelidir. Cümle (çözümleme) yöntemi ile ilkokuma ve yazmaya, öğrencilerin anlayabileceği kısa emir cümleleri ile başlamalı, zamanla bu cümleler kelimelere, kelimeler hecelere bölünmelidir. Daha sonra heceler içindeki harflerin sesleri sezdirilmeye çalışılmalıdır. Bu çözümlemeler sonunda elde edilen kelime, hece ve sezilen harflerle yeni cümle ve kelimeler kurularak kısa, anlamlı okuma metinleri oluşturulmalıdır.

\section{KAYNAKLAR}

Aydoğdu, M.K. ve Aköz, G. (1960). Normal Harflerle İlkokuma-Yazma Ögrretimi, Ankara: Sevinç Matbaası.

Baymur, F. (1947). İlkokuma ve Yazma Öğretimi (ikinci basım) İstanbul: İnk1lap Kitapevi.

Binbaşıŏlu, C. (2004). İlkokuma ve Yazma Öğretimi, Ankara: Nobel Yayın Dağıtım

Bloom, S.B. (1995). Insan Nitelikleri ve Okulda Öğrenme, (Çev. Durmuş Ali Özçelik) İstanbul: Milli Eğitim Basımevi

Cemaloğlu, N. (2000). İlkokuma Yazma Öğretimi, Ankara: Nobel Yayın Dağıtım Ltd. Şti.

Çınar, İ. (2002). Kuram ve Uygulamalarıla İlkokuma-Yazma Öğretimi Malatya: Öz Serhat Yayınları.

(2004). Birleştirilmiş sınıflı İlköğretim Okullarında İlkokuma Yazma Öğretimine İlişkin Bir Araştırma. Inönü Üniversitesi Eğitim Fakültesi Dergisi, Cilt 5. ( 7).ss.31-45.

Freire, P. \& Macedo,D. (1998). Okuryazarlı: Sözcükleri ve Dünyayı Okuma. (Çev. Serap Ayhan) Ankara: İmge Kitapevi.

Göğüş, B. (1968). İlkokullarda Türkçe: Öğretmen Kılavuzu; İstanbul: Milli Eğitim Basımevi. 
(1982) Türkçe: Öğretmen Klavuzu; Temel Eğitim Okulları 1, 2, 3 Sınıflar. İstanbul: Milli Eğitim Basımevi.

Güneş, F. (1997). Okuma Yazma Öğretimi ve Beyin Teknolojisi Ankara:

Ocak Yayınları.

(2000). Uygulamalı Okuma-Yazma Öğretimi, Ankara: Ocak Yayınları. Gray.W.S.(1975). Okuma Yazma Öğretimi, İstanbul: Milli Eğitim Basimevi.

Kavcar,C., Oğuzkan, F. ve Sever,S.(2004). Türkçe Öğretimi (7.Bask1).Ankara: Engin Yayınevi.

Köksal, K. (2001). Okuma Yazmanın Öğretimi (2. Baskı) Ankara: Pegem A Yayınevi.

MEB (1997). İlköğretim Okulu Türkçe Eğitimi Yazı Programı Tebliğler Dergisi, Kasım Say1:2482

MEB (2004). Illköğretim 1,2,3,4,5 Türkçe Programı (Taslak) Ankara: Milli Eğitim Basımevi.

MEB (1968). Illkokul Programı. İstanbul: Milli Eğitim Basımevi.

Öz, F. (1998). Uygulamalı Ilkokuma Yazma Öğretimi. Ankara: Anı Yayıncılık. 